\title{
A dimensão filosófica do Meister de Goethe e do Gato Murr de Hoffmann
}

\author{
Marco Aurélio Werle - USP
}

De início cabe situar brevemente, no campo da recepção filosófica, o romance de Goethe, Os anos de aprendizado de Wilhelm Meister $^{1}$, para, em seguida, estabelecer alguns paralelos entre esse romance e o de Hoffmann, intitulado Reflexões do Gato Murr.

A obra de Goethe apresenta, na forma de romance, uma questão filosófica central que anima o Idealismo alemão e o Romantismo, no âmbito de certa recepção do legado da filosofia kantiana, em particular da terceira crítica. O conhecido fragmento 216 da revista Ateneu, que põe o Meister ao lado da Doutrina da Ciência de Fichte e da Revolução Francesa, como as maio-

${ }^{1}$ Que me seja permitido remeter ao artigo "Teatro, formación y vida en el Wilhelm Meister de Goethe", publicado em Estudios de filosofia, 2013, 47, p. 107-119, no qual procuro realizar uma primeira aproximação ao que considero ser o problema filosófico que anima essa obra de Goethe. Mas esse artigo é apenas um embrião de um estudo maior em desenvolvimento. 
res "tendências" da época, é instrutivo para situar o romance de Goethe. Pois, efetivamente, Goethe procura, consciente ou inconscientemente, refletir sobre a possibilidade da ação humana a partir dos ideais da Revolução Francesa, e o faz no horizonte do princípio da subjetividade; encampado com muita energia pela filosofia de Fichte no ambiente pós-kantiano. O termo "tendência" é importante, pois no Meister coloca-se uma perspectiva que surgiu naquele momento, mas que não se apresentou imediatamente em toda a sua abrangência possível: a ideia da formação do espírito humano é justamente uma tendência. No centro do romance está colocada a questão de como o ser humano pode efetivar-se no mundo, este que, a partir da Revolução Francesa, a nos fiarmos pela leitura de Lukács $^{2}$, coloca o seguinte dilema: em que medida é possível realizar tanto a individualidade quanto a sociabilidade, no momento em que são abolidas as diferenças de classe entre os homens e o ser humano é tomado como universal concreto?

Essas questões são debatidas na correspondência de Goethe e Schiller (entre 1794-97). Schiller interpreta o Meister mediante categorias da terceira crítica de Kant, por exemplo, quando afirma que a atividade de Meister possui uma conformidade a fins sem um fim determinado, e que o Meister realiza o princípio do idealismo, a saber, que a ideia (a formação plena) se coloca na contingência, mas ao mesmo tempo não pode realizarse nela, justamente devido a seu caráter ideal e infinito. Pode-se dizer que Goethe, inspirado ou conduzido por Schiller, transpõe

${ }^{2}$ No ensaio traduzido como posfácio à tradução brasileira do romance de Goethe, Lukács afirma: "A realização do ideais humanistas é nesse romance não só o parâmetro para julgar as diversas classes e seus representantes, como também a força propulsora e o critério de ação de todo o romance" (Goethe, 2006, p. 586). 
o jogo das faculdades da mente, presente na Crítica do Juízo, para uma dimensão de vida e de objetivação do homem na existência como um todo.

Autores tão díspares como Friedrich Schlegel e Hegel seguem, grosso modo, em suas interpretações, essa mesma linha inaugurada por Schiller, que possui fortes vínculos com a proposta da educação estética da humanidade. Em Conversa sobre a poesia, Schlegel nos diz que o romance tem duas partes, uma ligada ao teatro e outra à vida. Em termos mais detalhados, refere-se principalmente em três momentos de sua obra ao romance de Goethe: na resenha que fez do Meister, em 1798, no Conversa sobre a poesia, de 1800, e por ocasião de uma resenha das obras de Goethe, do ano de 1808. Hegel, por sua vez, nos Cursos de estética, equilibra o romance entre a poesia do coração e a prosa das relações/do mundo (no capítulo sobre a poesia) e como sendo uma forma derivada do romanesco na época moderna (na seção sobre a forma de arte romântica) .

A partir dessas chaves de leitura, a kantiana da terceira crítica, a romântica e a idealista, indicadas aqui apenas em linhas gerais, pode-se dizer que o romance de Goethe sustenta a ação humana no âmbito de dois princípios: o da poesia (experiência pelo teatro) e o da vida (ação social, prática e econômica). Mas, nenhum dos dois princípios acaba predominando, pois ainda que ambos sejam momentos essenciais de afirmação do homem no mundo - já que se trata da dicotomia entre subjetividade e objetividade -, nenhum deles pode se impor de modo unilateral, sob pena de pôr a perder a própria ideia, como um todo ou totalidade, de homem, e, com ela, a de formação. Essa "indefinição" diante da poesia e da vida prática, que na verdade exprime um equilíbrio ou relação dialética especulativa, é o que justamente 
faz do Meister uma criação poética singular, no momento em que surge. Na verdade, um princípio é a crítica do outro, o que significa, em linguagem kantiana, que há um jogo entre imaginação e entendimento. (Em linguagem hegeliana, poder-se-ia dizer que os dois princípios estão em conflito, numa oposição dialética em si e para si. Para isso aponta a equação: poesia do coração e prosa do mundo.)

Esse leitmotiv de reciprocidade entre arte e vida, imaginação e entendimento, poesia do coração e prosa do mundo ou até entre poesia e economia (se pensarmos nos breves apontamentos de Novalis sobre o romance de Goethe) é percebido tanto pelo idealismo quanto pelo romantismo, e encontra-se, de modo bastante complexo, através dos oito livros do romance. São muitos detalhes e níveis estruturais que entram em questão, e não poderíamos abordá-los aqui. Primeiramente, coloca-se a própria noção de romance de formação, no qual se desdobra uma crítica ao teatro como gênero, seja pela noção de Teatro Nacional Alemão, a que se ligam as várias interpretações da obra de Shakespeare, em particular do Hamlet, que é lido sob uma chave orgânica (décimo terceiro capítulo do quarto livro do Meister: imagem de um carvalho plantado num vaso que não o comporta), seja pela acolhida de Shakespeare e na discussão das diferenças entre poesia dramática e romance. Tais observações sobre o teatro no interior de um romance apontam para um intrincado deslocamento de paradigma: o teatro, como doador de sentido para toda uma época (século XVIII), precisa agora abrir espaço para o romance (que será a marca do novo mundo: século XIX), seja dando lugar ao romance, seja inserindo-o como dimensão épica indispensável para os novos tempos. Tudo isso articula-se no plano de um sofisticado desdobramento de caracteres, que se 
apresenta tanto na figura de Meister e seu percurso formativo quanto na relação entre a sua individualidade e a dos demais personagens (esse ponto foi bastante ressaltado por Schiller). E, mais para o fim do romance, temos o caráter da Sociedade da Torre e uma inflexão para o campo de questões práticas, que envolve planejamentos sócio-econômicos, tais como a divisão da terra, abolição dos estamentos, a posição da mulher, da família, etc.

Parece-me importante não enquadrar o romance apenas no gênero romance de formação, usualmente tomado como mero gênero literário que possui alguns contornos, tal como o da formação do indivíduo e seus percalços. Pois, quando se pretende resolver rapidamente seu enredo a partir de uma fórmula literária, comparando essa obra a outras, inscrevendo-a simplesmente no quadro da história da literatura, perde-se assim sua dimensão filosófica própria.

$$
* * *
$$

As Reflexões do Gato Murr (1820-21), de E. T. A. Hoffmann, trazem uma proposta análoga à de Goethe, que, ao acentuar elementos distintos, permite tanto a percepção de novas dimensões do problema filosófico que surge em Goethe quanto, justamente por isso, iluminar e enriquecer a própria proposta goetheana ${ }^{3}$. Por ter sido escrita quase 25 anos depois do Meister, a obra de Hoffmann possibilita, particularmente, compreender o projeto de Goethe segundo um contexto já avançado do século XIX, de modo que se acrescentam novos dados ao problema históricotemporal.

Numa primeira comparação, notamos que as várias etapas

\footnotetext{
${ }^{3}$ Karin Volobuef indica que o Gato Murr encontra-se na linha do romance de formação (Volobuef, 1999, p. 44).
} 
que envolvem a formação de Meister concernem igualmente ao gato Murr: a experiência da infância; a viagem (no caso de Murr não é de uma cidade a outra, mas da casa ao telhado e de um telhado a outro); a descoberta do amor (Mariana e Miesmies, respectivamente), a experiência da traição (no caso do Murr, ocorrem inclusive duelos); a experiência da amizade (em Meister temos as peripécias com os grupos teatrais e seus integrantes, alguns deles de personalidade bastante forte); o desgosto com os homens (em Murr é forte a experiência da vida boêmia: "você caiu na farra, amigo Murr?" (Hoffmann, 2013, p. 285), pergunta o dono Abraham, que para "domar a fera" administrará três copos de pura aguardente de arenque); a entrada em sociedade, da Torre, no caso de Meister, da irmandade dos gatos, no de Murr; a ideia de ser escritor e intelectual, etc. No caso de Kreisler, temos também a crítica ao ambiente da corte e a experiência do tédio, por exemplo, na composição do tenente (Hoffmann, 2013, p. 105-106), que constitui um assunto central do terceiro livro do romance de Goethe.

O título original: Lebens-Ansichten des Katers Murr nebst fragmentarischer Biographie des KapellMeisters Johannes Kreisler in zufälligen Makulaturblättern (1819-22) [As impressões de vida do Gato Murr e fragmentos da biografia do capelão Johannes Kreisler, a partir de páginas casuais borradas], embora seja um pouco longo e inapropriado para uma publicação, possui a vantagem de desfazer o equívoco que o título abreviado, que saiu na edição brasileira, pode sugerir: Reflexões do Gato Murr. Pois a obra em si não se refere a meros pensamentos ou reflexões de um gato vaidoso, egocêntrico e atrevido. Por mais que seja engraçado que um gato leia, escreva e seja um intelectual, a obra não trata de meras impressões de um animalzinho en- 
graçado, como se estivéssemos diante de uma obra da literatura meramente "fantástica".

Aliás, é preciso situar devidamente esse motivo do animal que fala e pensa, isto é, o recurso ao elemento animal no romance de Hoffmann, tendo como pano de fundo o gênero conto de fa$\mathrm{das}^{4}$, muito em voga no Romantismo, e também o gênero fábula, muito debatido desde o século XVIII. Parece óbvio, entretanto, que não se trata apenas de colocar na boca de um gato nem aquilo que seria meramente do âmbito do fantasioso e fantástico, ligado ao reino animal e à natureza ou à uma dimensão inconsciente, nem também de supor, como pensaram alguns a respeito da fábula no século XVIII, que o animal é um representante "moral" daquilo que fazem e pensam os homens. Pode ser instrutivo lembrar aqui um ensaio de Herder, intitulado Sobre imagem, poesia e fábula, de 1781, no qual ele justamente critica a posição de Gottsched, que entende o animal nas fábulas como enunciador do maravilhoso, e a posição de Lessing, que vê a função do animal na fábula como sendo um portador de traços humanos. Para Herder, porém, os animais cabem na fábula porque o homem possui uma espécie de analogia com o modo de ser dos animais, não no plano desse ou daquele traço, e sim enquanto totalidade sensitiva, que atesta a nossa própria origem e condição de seres sensitivos (cf. Herder, 1994, p. 662-65).

Se considerarmos o Gato Murr no campo do problema que anima o romance de formação de Goethe, a saber, de questionamento da liberdade humana e de suas matrizes de efetivação, vê-se que o principal motivo de o personagem principal ser um gato remete ao princípio da própria concepção que Hoffmann

${ }^{4}$ Hoffmann faz menção à obra de Ludwig Tieck, $O$ gato de botas, de 1797, como antecessor do gato Murr (cf. Hoffmann, 2013, p. 48). 
tem da afirmação do ser humano enquanto tal. O fato de o personagem central ser um gato (e ainda por cima um gato [macho], ein Kater, nicht eine Katze) remete a um aspecto de irredutibilidade da ação humana, a algo rebelde e indomável. O que interessa é a proposta de afirmação da subjetividade ou mesmo dos chamados ideais de liberdade, oriundos da Revolução Francesa, que na concepção de Hoffmann não podem ser resolvidos totalmente no plano do meramente racional e humano, mas antes devem englobar aspectos ligados aos instintos e a uma certa plasticidade animal presente no campo humano. Com isso, surge no romance de Hoffmann todo um lado, por assim dizer, mais próximo do princípio do mal e dos chamados vícios humanos (como a vaidade, a falta de solidariedade, egoísmo, etc.), que não entra na obra de Goethe, pelo menos não com a mesma intensidade.

O Gato Murr põe em questão a possibilidade mesma de realização dos ideais humanistas, os quais encontram-se em Goethe presentes como algo, por assim dizer, natural e em estado "puro", efeito de certa "euforia" pós-revolucionária. Toda a atmosfera e disposição anímica da obra de Goethe é construída na direção de uma sensação de felicidade e satisfação, em suma, no estilo clássico que animava Goethe naquele momento, depois da viagem à Itália e logo após os grandes desdobramentos da filosofia alemã. Essa atmosfera confere inclusive um tom bastante ingênuo ao personagem central e mesmo ao enredo: é como se um problema moderno fosse resolvido no plano de paradigmas da Antiguidade. É outra articulação profunda do romance de Goethe: realizar o equilíbrio entre os modernos e os antigos, o que, na linguagem de Schiller, remete às categorias do ingênuo e do sentimental. No Gato Murr, ao contrário, entra em cena 
um elemento sombrio da existência humana ${ }^{5}$, com o qual a Revolução Francesa também teve que contar. Em outras palavras, no romance de Goethe, a trama inteira da formação humana se desenvolve no plano estritamente apaziguado e harmonioso da vida social; aposta-se muito no humanismo, no equilíbrio e numa certa ideia de sociabilidade, do "repouso em si mesmo" (tal como Hegel e Winckelmann leem os gregos). Reina uma visão de otimismo diante do homem. Já em Hoffmann, aflora um lado mais obscuro, tenebroso e imprevisível na ação humana; não se teme mostrar o lado sórdido, egoísta, de desconfiança e de ceticismo que toma conta dos personagens. É como se Hoffmann alertasse: esse lado não pode ser excluído, caso queiramos enfrentar de fato o tema da efetivação da liberdade humana.

É curiosa a sátira que Hoffmann faz, na boca do gato Murr, do imperativo categórico kantiano. Murr percebe que o princípio de que "cada um deve agir de tal modo que o motivo que o levou a agir possa ser convertido em lei universal" (Hoffmann, 2013, p. 142) não se adapta ao modo de agir de seu amigo, o poodle Ponto, dotado de uma esperteza mundana, para quem a honestidade deve ser praticada, mas apenas nas pequenas coisas e diante dos olhos dos seres humanos, mas não vale de modo incondicional. O imperativo categórico é, assim, inscrito no campo de um saber meramente livresco, que se choca com a experiência do "cidadão do mundo", do poodle Ponto, para quem valem antes os preceitos práticos, tais como aquele que diz: "antes perder a lã que a ovelha" (Hoffmann, 2013, p. 142). Em outro momento (no qual se apresenta uma alusão contrária ao Cristianismo), o gato Murr também rejeita a expressão: "peço

${ }^{5}$ Ressaltado por Peter-André Alt no livro Ästhetik des Bösen. München: Beck, 2010. 
humildemente perdão" (Hoffmann, 2013, p. 50).

$* * *$

Antes de entrar em alguns temas que se apresentam tanto no Meister como no Murr, é preciso explicitar alguns aspectos formais estilísticos de composição, sobre o modo como se apresenta a narrativa ou os planos narrativos nas duas obras. O tom da narrativa de Hoffmann, como já foi frisado, é mais negativo, "pessimista", ou menos "otimista". No caso de Goethe, as expectativas ainda frescas da Revolução Francesa e do "idealismo nascente" (por volta de 1795) fazem com que a obra seja "otimista", equilibrada, "bela" e harmoniosa (sob o influxo do ideal clássico grego), sendo conduzida de maneira segura pelo narrador e estando impregnada de humanismo. Os limões de Goethe, mencionados na conhecida canção de Mignon ${ }^{6}$, que abre o terceiro livro do Meister, remetem a uma terra onde brilha o sol, a Itália, para a qual o ser humano anseia retornar, ao contrário dos limões parodiados por Hoffmann, que são ardidos, na canção da moça que inspirou o príncipe Hektor a voltar a Nápoles: "você conhece o país onde ardem os limões" (Hoffmann, 2013, p. 208). Grosso modo, se temos de um lado o entusiasmo de Goethe pelos ideais humanistas, de outro há Hoffmann, que já está se aproximando da atmosfera de pensamento pré-revolução de julho de 1830, e de um Schopenhauer ou Nietzsche.

A dupla narrativa, a que envolve o gato Murr e a que envolve Johannes Kreisler, indica duas histórias que são independentes, e remetem uma à outra. A título de informação, essas narrativas paralelas, uma interrompendo a outra, se devem ao "vandalismo

${ }^{6}$ A primeira estrofe: "Conheces o país onde florescem os limoeiros,/ em meio à folhagem escura ardem os pomos de ouro,/Uma brisa suave sopra no céu azul./E o mirto e o louro em silêncio crescem?/Não o conheces?/Pois lá, para lá,/Quisera contigo, meu bem amado, ir!". Goethe, 2006, p. 151. 
literário do bichano", como nos informa Hoffmann no prefácio do editor, que "rasgara sem cerimônia um livro impresso encontrado na casa de seu dono, e arbitrariamente empregara as folhas, ora como base para o seu texto, ora como mata-borrão" (Hoffmann, 2013, p. 22).

Com efeito, a história do gato Murr é mais bem humorada e divertida e apresenta maiores contrastes entre os diferentes momentos do enredo. É aqui que se insere propriamente o caráter de romance de formação dessa obra de Hoffmann. Já a narrativa paralela de Kreisler é mais pesada, mais trágica e até mesmo mais estranha e "pedante", sem humor ou, em alguns casos, com um humor ácido ou sarcástico (na composição do tenente, já mencionada anteriormente). É uma espécie de romance de artista, com vários ingredientes que só dizem respeito à arte, como as longas discussões sobre música e os dilemas de um músico. Em suma, o enredo gira em torno da dificuldade do artista com o mundo. O Gato Murr também apresenta esses aspectos, do intelectual que se choca com o mundo, mas a certeza de sua "superioridade" intelectual faz com que passe facilmente por cima dessas "dificuldades", que no caso de Kreisler se afiguram como verdadeiros obstáculos, difíceis de serem superados. Devemos lembrar que nos primeiros livros do Meister de Goethe insinua-se também o gênero "romance de artista", a ser superado ou incorporado pelo gênero maior, o romance de formação.

Parece evidente que o leitor simpatiza mais com a narrativa do Gato Murr, pois ela prende mais a atenção, devido à progressão dotada de uma expectativa. Isso faz com que por vezes se fique tentado a saltar o trecho dedicado a Kreisler, para poder acompanhar melhor o enredo do Gato Murr, muito em- 
bora existam ligações entre as duas histórias. O próprio Mestre Abraham, construtor de órgãos, é tanto o dono carinhoso do gato Murr quanto amigo de Johannes Kreisler. Poder-se-ia também ressaltar algumas semelhanças entre Murr e Kreisler, embora a disposição anímica de ambos seja distinta.

A narrativa envolvendo Kreisler é feita na terceira pessoa, ao passo que junto ao gato Murr é este que narra sua vida na primeira pessoa. Isso faz com que a narrativa do Gato Murr seja mais compacta, marcada por sua presença constante, plena, dotada de uma vivacidade maior, pois, como não podia deixar de ser, gira sempre em torno do próprio gato Murr. Já a narrativa de Kreisler é mais solta, não tão amarrada ao personagem principal: apresenta vários elementos da corte de Sieghartsweiler, tendo como um dos tópicos as intrigas e bizarrices da corte. Um exemplo bizarro é o jovem príncipe Ignácio, de vinte e poucos anos, obcecado pela atividade de colecionar xícaras e que apresenta o que se poderia designar como síndrome de Peter Pan (Hoffmann, 2013, p. 180-81). Trata-se de uma imagem da infantilização do pensamento da corte. Muitos desses aspectos em Hoffmann lembram o terceiro livro do Meister de Goethe, quando também nos são mostrados aspectos bizarros do mundo da corte.

$* * *$

Há uma preocupação constante de Hoffmann em realizar paródias de Goethe. O exemplo dos limões é o mais flagrante. Além disso, a expressão de Goethe, que abre sua Viagem à Itália: "também eu estive na Arcádia" (et in Arcadia ego), torna-se no Gato Murr o fato de ter vivido uma experiência amorosa no telhado com a gata Miesmies (Hoffmann, 2013, p. 227) (também a menção à expressão "arcádia do amor", Ibid. p. 238). Igual- 
mente, a terceira parte do romance é intitulada: "Os meses de aprendizagem" (Hoffmann, 2013, p. 237). Já no plano dos personagens, se, de um lado, temos no Murr a Miesmies que canta, no Meister, por outro lado, Mariane é tida como a atriz instável, e ambas aparentemente "traem" seus amantes. No Murr temos um episódio em que a casa pega fogo; no Meister o teatro pega fogo. O poema de Goethe Ergo Bibamus é objeto de troça e várias vezes repetido pelo beneditino, quando Kreisler chega ao mosteiro. Também a temática do destino e do acaso, presente em Goethe, é mimetizada, embora no Murr toda a trama siga um percurso mais solto. Parece não haver um caminho ou uma rota de formação, como no Meister. Aliás, o destino de intelectual ou o desejo de nomeada de Murr (que lembra o desejo de Meister de escrever uma peça de teatro) é retratado com ironia e humor: por exemplo, com a publicação de suas obras "imortais": Pensamento e intuição - O gato e o cão, e Sobre ratoeiras - Influência no modo de pensar e na destreza felina. Para a realização dessa última obra, infelizmente, o gato Murr, após ter sido isolado por seu dono, não tem acesso à biblioteca do mesmo. Mas isso não chega a fazer diferença, pois, como diz Murr de si mesmo, "a uma mente altamente filosófica não escapariam jamais as mais secretas relações da vida" (Hoffmann, 2013, p. 104). De modo que essa obra sobre as ratoeiras surgiu do puro dom de observação da interação entre as ratoeiras e os gatos. Diz Murr: "como gato de nobre e autêntica condição, indignava-me constatar como aquelas máquinas fatais com sua ação eficaz provocavam grande sonolência nos jovens gatos" (Hoffmann, 2013, p. 104).

$* * *$

Partindo da fórmula cunhada por Hegel, do conflito entre a 
poesia do coração e a prosa da vida, ressalta-se a dimensão de crítica e análise social presente nos dois romances. Embora ambos rejeitem a sociedade de corte, a sociabilidade nos dois romances se faz presente de modo mais forte a partir de desdobramentos sobre a posição e o sentido da burguesia ou, se se preferir, da classe ou estamento burguês. É ilustrativo lembrar, a esse respeito, a interpretação de Habermas em Mudança estrutural da esfera pública (Habermas, 1962, p. 26-27). Partindo da conhecida carta que Meister escreve no terceiro capítulo do quinto livro (também analisada por Erich Auerbach em Mimesis), Habermas a considera como um testemunho do fim da esfera pública em sua forma representativa.

Nesse quinto livro, vemos Meister finalmente optar pela vida de ator, após receber uma carta de seu cunhado Werner, seu amigo de juventude que agora se ocupa do comércio. Werner comunica a Meister a morte de seu pai. Werner, que já defendia e seguia ardorosamente desde a juventude o mundo prático do comércio, funciona no romance como uma espécie de antípoda de Meister, no que diz respeito à vocação de vida. Embora sejam amigos íntimos, Werner não consegue, já desde o segundo livro do romance, compreender a paixão de seu amigo pelo teatro, de tal modo que, a partir de um sentimento de realizar uma boa ação, toma a peito a tarefa de tirar o amigo do mau caminho. Do seu ponto de vista, uma ocupação digna para um homem tem de passar por uma atividade produtiva e efetiva no âmbito da vida concreta social. E, na carta que agora envia a Meister, é justamente o elogio dessa vida que novamente faz, tendo diante de si a imagem de seus filhos, que aos poucos também trilham o caminho do pai.

Diante desse elogio da vida burguesa voltada para a ativi- 
dade econômica, Wilhelm Meister prefere, no entanto, um ideal de vida mais elevado e nobre, que lhe permita uma verdadeira liberdade que, segundo ele, somente os nobres possuem, mas não quem nasceu numa classe inferior, na burguesia e que não tem outra saída senão o trabalho. E assim, escreve a Werner: "Para dizê-lo em uma palavra, desde minha primeira juventude formar-me a mim mesmo foi sempre meu objetivo e meu propósito" (Goethe, 1997, p. 306). É através do teatro que Meister imagina conseguir atingir, pelo menos idealmente, a liberdade que a vida burguesa estreita impede. O nobre, ao contrário do burguês, considera ele, não necessita deste caminho, pois ele já é por si mesmo livre em sua maneira de ser. Para Meister, porém, somente no mundo da aparência, sobre o palco, será possível alcançar uma formação harmoniosa de todos os dons e habilidades; ali, é possível ser e parecer ao mesmo tempo (Goethe, 1997, p. 309).

O burguês está fadado a não conseguir mais realizar o ideal da representação pública, pois, ocupado com o trabalho, fica em princípio excluído de qualquer possibilidade de ingresso na esfera pública". Cito Habermas: "Wilhelm aparece diante de seu público como Hamlet e, a princípio, também com êxito. No entanto, o público já é portador de uma outra esfera pública, que não tem mais nada em comum com a esfera pública representativa. Nesse sentido, a missão teatral de Wilhelm Meister tem de fracassar" (Habermas, 2014, p. 113). Nas palavras do próprio Goethe: "um burguês pode adquirir méritos e desenvolver seu espírito a mais não puder, mas sua personalidade se

7 Comentário citado a partir da série da Reclam, dedicada ao Meister. E. Bahr, (hrsg.) Johann Wolfgang Goethe: Wilhelm Meisters Lehrjahre, Erläuterungen und Dokumente. Stuttgart: Reclam, 1982, p. 114. 
perde, apresente-se ele como quiser" (Goethe, 1997, p. 306/Goethe, 2006, p. 284-85). Se, de um lado, o nobre se relaciona com as mais distintas pessoas, confere a si mesmo um porte distinto, possui uma graça majestosa, é uma pessoa pública, em suma, não conhece limites, por outro lado, o burguês, caso aspirasse a essas prerrogativas, fracassaria por completo, pois nada se ajusta melhor a ele que o puro e plácido sentimento do limite que lhe está traçado. Como diz Goethe: "não lhe cabe perguntar: que és tu, e sim: que tens tu?" (Goethe, 1997, p. 308/Goethe, 2006, p. 285).

Pode-se dizer que esse problema se põe tanto no Meister quanto no Gato Murr. Aliás, esse último apresenta um grau bem maior de falta de representatividade, ao passo que no Meister esboçam-se pelos menos algumas alternativas e pontos de apoio. O movimento do Meister consiste inclusive em o burguês elevar-se ao patamar simbólico do nobre, o que lhe permitirá desenvolver-se mais plena e livremente. Já no Gato Murr, essa opção de aceder à nobreza não se põe em nenhum plano possível.

Em Goethe como em Hoffman há um conflito entre o que o ser humano gostaria de ser e a realidade do mundo, que se pode também formular como sendo o choque entre o mundo da imaginação e da cultura (mundo poético) com o mundo real e objetivo (mundano e econômico). Em Goethe, põe-se o conflito burguesia/aristocracia, já em Hoffmann surge o tema do filisteu. É curioso que no Werther, romance da juventude de Goethe, surja claramente a figura do filisteu, mas que está ausente no Meister.

O tema do filisteu se põe pela primeira vez em Hoffmann no começo do segundo volume (ou terceira parte) e se revela um 
conceito que surpreende a inteligência do gato Murr, que não tinha ideia do que vinha a ser um filisteu. A terceira parte segue-se ao episódio da "arcádia do amor", ocorrida na segunda parte. E começa com a preguiça que de repente toma conta do gato Murr, notada até por seu dono Abraham. Mas é seu amigo Muzius que o adverte, observando que ele está correndo o perigo de se tornar um "abominável filisteu" (Hoffmann, 2013, p. 241). E pior, com sua preguiça e aspecto gordo e dotado de intelectualidade, Murr corre o risco de tornar-se não apenas um filisteu abominável, mas um "filisteu erudito" (Hoffmann, 2013, p. 242). No caso da narrativa paralela concernente a Kreisler, a temática do filisteu é indicada pela contraposição entre a etiqueta e o coração, no âmbito da vida da corte (no episódio da doença que acomete a princesa Hedwiga) (Hoffmann, 2013, p. 248).

Mas, quais são as características de um filisteu, ou melhor, de um gato filisteu? Basicamente, é um sujeito bem educado, que mantém a etiqueta, vangloria-se de suas qualidades, da posição que alcançou na vida, de suas virtudes, e é vaidoso quanto à sua imagem, que procura conservar impecável. Em suma, "o gato filisteu permanece, de preferência, sob a estufa de seu lar, onde se sente protegido, pois o telhado aberto lhe provoca vertigem" (Hoffmann, 2013, p. 259). Chocado com essas revelações do amigo Muzius, Murr passa a integrar a irmandade dos gatos, como forma de reação ao estilo de vida filisteu e como o único modo de saída dessa condição. Essa irmandade é liderada pelo gato sênior, o gatarrão Puff (Hoffmann, 2013, p. 260). Claramente, é mimetizada aí a alternativa goetheana da Sociedade da Torre, liderada pelo Abé.

Com isso, coloca-se em discussão o significado dessas "saídas", 
apresentada por Goethe para o burguês e por Hoffmann para o filisteu, ou seja, a solução da Sociedade da Torre e a ideia da Irmandade nos dois romances. Murr chega à irmandade porque percebe o perigo de se tornar um filisteu. A irmandade possui, assim, algo de utópico, uma espécie de associação fraterna e comunitária: "o gato de nossa irmandade", diz o gato Muzius, "é aberto, sincero, desinteressado, corajoso e sempre prestativo junto aos amigos, sem ater-se às considerações que não tenham sido impostas pela honra e pela moral, enfim, o gato de minha irmandade é o exato antípoda do filisteu, e espero que você não hesite em abandonar o filisteísmo e converter-se a bravo gato decente" (Hoffmann, 2013, p. 259). Já no caso de Goethe, a Sociedade da Torre possui algo de seleto e elitista, cujo lema é elevar o indivíduo, no fundo para além da própria condição burguesa e o acento está dado no elemento da cultura ou da educação para a cultura. Nos últimos livros do Meister colocase também uma série de planejamentos de ordem prática, os quais revelam a feição da Sociedade da Torre, que defende a abolição dos privilégios dos nobres sobre a terra, ou seja, defende uma reforma agrária, bem como possui planos de compra de terras na América. Enfim, A Sociedade da Torre tem como intuito proteger os homens diante do mundo capitalista emergente, integrá-los, etc. Outro ponto a ser explorado em Goethe diz respeito ao contraste entre Werner, "hipocondríaco do trabalho", uma espécie de burguês "desprotegido" e Meister, um burguês enobrecido. Ou seja, há em Goethe a possibilidade de se continuar sendo burguês sem tornar-se filisteu.

Se tentarmos resumir a diferença entre a figura do burguês em Goethe e do filisteu em Hoffmann, ela reside no fato de que Goethe apresenta o limite da vida burguesa como um dado a ser 
superado na direção de um ideal nobre de vida. Já em Hoffmann, o filisteu já é, de alguma forma, aquele burguês de Goethe que se resignou em ser burguês, aprendeu a viver com a concepção do limite, o qual já não o incomoda mais. Pelo contrário, tornou-se um ideal de vida: o filisteu cultiva justamente sua vida limitada como um ideal. Desapareceu a noção de "revolta" e possibilidade de superação. Dessa forma, a única saída para o gato Murr é opor-se a esse estilo de vida que estava tomando conta dele.

Nessa diferença entra em questão um fator de ordem histórica: o romance de Goethe foi concebido logo após a Revolução Francesa, quando os ideais ainda estavam frescos, não surgira Napoleão, etc. É um ponto ressaltado por Lukács. Um dos grandes méritos da obra de Goethe reside na transposição literária do espírito do momento histórico: no fundo, Goethe não poderia ter escrito o Meister nem antes nem depois daquele momento. A questão de Goethe só pôde surgir nesses anos de 1794-97, nem muito próximos da Revolução, quando tornou-se possível perceber alguns de seus exageros, nem muito longe dela, quando seus ideais conservavam forte apelo, aspecto esse que foi se enfraquecendo gradativamente depois de 1800.

Ora, essa capacidade condensar numa obra um momento único e fundamental na história do Ocidente é o que permite a Goethe discutir o tema da vida burguesa, de suas vantagens e desvantagens, de um modo incomum. Diante disso, a seguinte caracterização do burguês, no trecho da carta a Werner no livro V, torna-se emblemática: "De que me vale fazer um bom ferro, se meu próprio interior está cheio de escórias?" (Goethe, 1997, p. 306/Goethe, 2006, p. 284). Em Hoffmann, por seu turno, quase 25 anos depois, esse tema não poderia surgir da mesma forma. Mesmo assim, a questão de fundo permanece, assumindo outra 
configuração: não será mais a crítica ao burguês, mas a crítica ao filisteu (tema que será muito caro meio século depois para Nietzsche), do burguês tornado filisteu (assunto que surge também no conhecido conto $O$ homem de areia).

$$
* * *
$$

Uma diferença de ordem estética entre o Meister e o Murr é a centralidade que neste assume a música e naquele o teatro. A presença dessas duas artes nos dois romances não deve ser tomada apenas como aleatória, ou como se resultasse de uma predileção artística e estética de Goethe e de Hoffmann, embora obviamente esse aspecto da afinidade dos autores com essas duas artes não deva ser de todo negligenciado. Goethe escreveu grandes peças de teatro, ao passo que Hoffmann compôs peças musicais e exerceu de modo primoroso a crítica musical. No entanto, o opção pelo teatro ou pela música como meio de formação aponta antes para diferentes modos de compreensão paradigmática da modernidade.

Essas artes dão certa tonalidade afetiva e plasticidade às duas obras, apontando para paradigmas de ação humana. O modo da interação humana pautada pela experiência musical é de um tipo mais interior e enigmático, ao passo que a guiada pelo teatro requer outros elementos, por assim dizer mais visuais ou públicos, o que muda muito a perspectiva de realização dos chamados ideais humanistas, e implica caminhos e percursos distintos. Com efeito, no Gato Murr é notável o predomínio de cenas de interior ou cenas que envolvem graus de intimidade maior, de introspecção (pequenos círculos, execução de duetos, diálogos quase musicados, etc.), ao passo que em Goethe necessariamente predomina uma riqueza mais visual e intuitiva, segundo a qual procura-se constantemente mostrar o ser humano 
em situações "públicas". Ora, essas duas opções apontam para o modo como ambos experimentam e exprimem a modernidade, a ação humana possível na modernidade.

No caso de Goethe, a presença do teatro se liga a uma longa tradição do século XVIII, que Goethe tanto ratifica como critica, posto que começa a estar em desacordo com o novo tempo. No romance de Goethe está colocada a pergunta: em que medida podemos pensar o homem ainda pelo paradigma da representação? Como o homem pode continuar a se representar num mundo que em certa medida possui a tendência ao bloqueio da representação? Em certa medida, Goethe responde incluindo a experiência teatral no campo das possibilidades de efetivação do humano, embora também aponte para o limite do ideal de vida que o teatro propõe. Enfim, sem entrar nesse assunto complexo que domina os cinco primeiros livros do Meister, o fato é que todo o enredo, a ação e os caracteres dos principais personagens do romance são dominados pelo paradigma teatral. Daí que o romance de Goethe é muito mais plástico, vivo e variegado, em termos de cenas e situações, do que o de Hoffmann.

Em Hoffmann, tudo gira fortemente em torno da música, seja como exemplo seja como marca característica dos personagens. O principais personagens, o próprio Murr, são eles mesmo música: os comportamentos se assemelham a movimentos musicais, a altos e baixos, a graves e agudos, a andantes e duetos, improvisos, etc. Por exemplo, a princesa Hedwiga é caracterizada como "uma melodia fluindo em notas claras" (Hoffmann, 2013, p. 227). No romance ela surge ora grave, ora aguda, revelando grandes oscilações e inconstâncias. Outro exemplo é Júlia, que Hoffmann caracteriza como uma "dissonância da harmonia celeste que reina na alma" (Hoffmann, 2013, p. 233). Ou seja, 
a música não é uma arte apenas empregada para os exemplos de expressão de erudição e de cultura, como se fosse externa à trama. Pelo contrário, o ritmo do enredo, muitas das manifestações dos personagens, por exemplo, os arroubos de Kreisler, suas mudanças repentinas de humor, as exaltações das personagens femininas, por exemplo de Hedwiga e mesmo a situação do primeiro encontro do gato Murr com a gata Miesmies, tudo isso passa pela característica musical: os agudos, os graves, os contrastes, os duetos, altos e baixos. Enfim, a música que dá o tom de tudo que se passa, imprimindo densidade às ações e aos personagens.

O predomínio do teatro em Goethe e da música em Hoffmann determina outras características. Se em Goethe temos muito mais ação e elementos de exterioridade, como os passeios e as viagens, em Hoffmann impera a atmosfera das aulas de piano em pequenos recintos. Os próprios personagens são mais interiores e hesitantes, dão a impressão de não serem muito aptos para uma ação objetiva.

\section{$* * *$}

No que concerne ao problema filosófico presente no romance de Goethe, e que é ao mesmo tempo central para a filosofia da época, pode-se dizer, pelos poucos elementos de contraste levantados entre a proposta de Goethe e a de Hoffmann, que o fundo permanece, embora a forma se modifique. Essa transformação da forma, porém, indica tanto as possibilidades de apresentação do problema filosófico, como também um certo esgotamento do problema, no plano da efetividade histórica. Ou seja, a proposta de "romance de formação" de Hoffmann não é uma simples variação daquilo que foi criado por Goethe, mas o prenúncio do destino que essa concepção terá ao longo do século XIX e XX. 
Colocar Hoffmann ao lado de Goethe permite, nesse sentido, uma tematização de uma certa modernidade, no horizonte de uma dialética entre o moderno e o contemporâneo.

\section{Referências Bibliográficas}

ALT, P. -A., Ästhetik des Bösen. München: Beck, 2010

BAHR, E. (hrsg.) Johann Wolfgang Goethe: Wilhelm Meisters Lehrjahre, Erläuterungen und Dokumente. Stuttgart: Reclam, 1982

GOETHE, J. W. Wilhelm Meisters Lehrjahre, Band 4, Werkausgabe in zehn Bänden. Köln: Könemann, 1997

de Nicolino Simone Neto. São Paulo: Editora 34, 2006

HABERMAS, J. Strukturwandel der Öffentlichkeit . Neuwied/Berlin:

Luchterhand, 1962

___. Mudança estrutural da esfera pública, tradução e apresentação de Denilson Luís Werle. São Paulo: Unesp, 2014 HERDER, J. G. Schriften zu Philosophie, Literatur und Altertum (1774-1787), hrsg. von Jürgen Brummack und Martin Bollacher, Band 4. Frankfurt am Main: Deutscher Klassiker Verlag, 1994

HOFFMANN, E. T. A. Lebens-Ansichten des Katers Murr. Franfkfurt am Main: Deutscher Klassiker Verlag, 1992.

- Reflexões do Gato Murr, tradução de Maria Aparecida

Barbosa. São Paulo: Estação Liberdade, 2013

VOLOBUEF, K. Frestas e arestas. São Paulo: Unesp, 1999.

WERLE, M. A. "O idealismo de Schiller no Meister de Goethe",

Revista Tempo Brasileiro, 2014

Goethe", Estudios de filosofia, 2013, 47, p. 107-119 
